\title{
EFFECT OF PLANTS MEAL FROM Eeichhornia crassipes AND Salvinia molesta ON GROWTH OF Pangasius sp.
}

\author{
Retno Cahya Mukti ${ }^{* 1}$, Ria Octaviani ${ }^{1}$
}

\begin{abstract}
Plant meals from Eichhornia crassipes and Salvinia molesta can be used as alternative ingredients for feed in aquaculture. The purpose of this study was to determine the effect of the use of plant meals as a feed on the growth of Pangasius. The experimental designed consist of three treatments and triplicates: P0: commercial feed (control); P1: feed with the addition of 25\% Eichhornia crassipes; P2: feed with the addition of 25\% Salvinia molesta. The results showed that plant meals in feed showed significantly different results on the growth of body weight, specific growth rate, and efficiency of Pangasius feed. The recommended treatment was the addition of Salvinia molesta with a weight growth value of $3.84 \mathrm{~g}$, a specific growth rate of $2.07 \%$, and feed efficiency of $59.96 \%$.
\end{abstract}

\section{Keywords: Water hyacinth, kiambang, feed, catfish}

\section{Pendahuluan}

Pakan merupakan faktor penting dalam kegiatan budidaya ikan. Sekitar $50-60 \%$ biaya produksi berasal dari pakan. Tingginya harga pakan di pasar disebabkan karena bahan baku yang digunakan masih berasal dari impor (Mukti et al., 2019). Dengan harga pakan yang tinggi dan harga jual ikan yang rendah menyebabkan keuntungan yang diperoleh pembudidaya ikan juga rendah. Oleh karena itu perlu dilakukan upaya untuk mengurangi penggunaan pakan komersil yaitu dengan penggunaan bahan alternatif sebagai bahan pakan ikan. Bahan pakan alternatif yang digunakan sebagai pakan ikan harus memenuhi beberapa persyaratan yaitu mengandung nutrisi yang cukup, harganya terjangkau dan mudah diperoleh (Suprayudi, 2011).

Eceng gondok (Eichhornia crassipes) dan kiambang (Salvinia molesta) merupakan jenis tanaman air yang dapat dijadikan sebagai bahan pakan artenatif. Menurut Astuti dan Indriatmoko (2018), eceng gondok dan kiambang merupakan jenis tanaman air yang banyak tumbuh di perairan yang berfungsi sebagai filter biologis akan tetapi pertumbuhan kedua jenis tanaman ini tergolong cepat dan dapat menyebabkan blooming sehingga tanaman tersebut juga seringkali dianggap sebagai gulma perairan. Eceng gondok dan kiambang belum banyak dimanfaatkan dengan baik oleh masyarakat sehingga berpotensi untuk dijadikan pakan ikan. Selain itu eceng gondok dan kiambang juga mengandung nutrisi yang cukup

\footnotetext{
*E-mail: retnocahyamukti@unsri.ac.id

${ }^{1}$ Program Studi Budidaya Perairan, Fakultas Pertanian, Universitas Sriwijaya

Jl. Palembang-Prabumulih KM 32, Indralaya, Ogan Ilir, Sumatera Selatan
} 
tinggi. Eceng gondok mengandung protein $12,40 \%$, lemak $4,72 \%$, BETN $30,81 \%$, dan serat kasar $19,9 \%$ (Yuniati et al., 2018) sedangkan kiambang mengandung nutrisi yaitu protein $19,56 \%$, lemak $3,25 \%$, karbohidrat $21,98 \%$, serat kasar $15,24 \%$, abu $14,74 \%$ dan air $49,19 \%$ (Iskandar dan Elrifadah, 2015)

Tanaman eceng gondok dan kiambang sudah banyak digunakan sebagai pakan ikan. Beberapa penelitian menunjukkan bahwa penggunaan eceng gondok dalam pakan ikan menghasilkan pertumbuhan yang tinggi diantaranya pada ikan gurame (Osphronemus gouramy L) dengan dosis $25 \%$ menggantikan tepung kedelai (Sulhi, 2015) dan pada ikan nila (Oreochromis niloticus) dengan dosis $10 \%$ (Razikin et al., 2019) sedangkan penggunaan kiambang terfermentasi juga sudah dilakukan pada ikan nila pada dosis 10\% (Warasto et al., 2013) dan pada ikan betok (Anabas testudineus Block) dengan dosis $20 \%$ (Ramadhana, 2020).

Ikan patin (Pangasius sp.) merupakan ikan omnivora yang dapat memanfaatkan pakan nabati. Oleh karena itu perlu dilakukan penelitian tentang pemanfaatan eceng gondok dan kiambang pada pakan terhadp pertumbuhan dan kelangsungan hidup ikan patin (Pangasius sp.).

\section{Metode}

Tempat dan Waktu

Penelitian ini dilaksanakan pada bulan September - Oktober 2019. Pemeliharaan ikan dilakukan di Laboratorium Dasar Perikanan, Program Studi Budidaya Perairan, Universitas Sriwijaya.

\section{Alat dan Bahan}

Alat yang digunakan berupa akuarium berukuran $30 \times 30 \times 30 \mathrm{~cm}$, aerator, selang aerasi, batu aerasi, termometer, $\mathrm{pH}$ meter, baskom, oven, blender, timbangan digital, penggaris, saringan, selang sipon, dan mesin pencetak pelet. Sedangkan bahan yang digunakan antara lain ikan patin dengan rata-rata ukuran panjang $7 \pm 0,5 \mathrm{~cm}$ dan berat $4 \pm 0,5 \mathrm{~g}$, pakan komersil, eceng gondok, dan kiambang.

\section{Rancangan Penelitian}

Rancangan penelitian berupa rancangan acak lengkap dengan tiga perlakukan dengan masing-masing tiga ulangan. Perlakuan yang digunakan adalah penggunaan tanaman air yang berbeda pada pakan ikan (Tabel 1).

Tabel 1. Komposisi dan proksimat pakan ikan patin

\begin{tabular}{lccc}
\hline \multirow{2}{*}{ Bahan } & \multicolumn{3}{c}{ Komposisi (\%) } \\
\cline { 2 - 4 } & P0 & P1 & P2 \\
\hline Pakan komersil & 100 & 75 & 75 \\
Eceng gondok & - & 25 & - \\
Kiambang & - & - & 25 \\
\hline Total & 100 & 100 & 100 \\
\hline
\end{tabular}




\begin{tabular}{lccc}
\hline \multicolumn{4}{c}{ Proksimat pakan } \\
\hline Protein (\%) & 26,04 & 23,26 & 24,63 \\
Lemak (\%) & 4,31 & 4,25 & 2,13 \\
BETN $^{1}(\%)$ & 53,14 & 53,09 & 53,05 \\
Serat kasar (\%) & 4,78 & 6,87 & 6,54 \\
Kadar abu(\%) & 11,72 & 12,53 & 13,65 \\
$\mathrm{GE}^{2}$ (kkal/kg) & 4042,68 & 3878,27 & 3754,54 \\
\hline Keterangan: ${ }^{1 B E T N}$ : bahan ekstrak tanpa nitrogen; \\
'GE: gross energy dihitung berdasarkan 1 g protein= 5,6 kkal; 1 g karbohidrat (BETN)=4,1 \\
kkal; 1 g lemak= 9,4 kkal (NRC, 1993)
\end{tabular}

\section{Persiapan Wadah}

Wadah yang digunakan berupa akuarium sebanyak 9 unit. Sebelum digunakan, wadah dibersihkan terlebih dahulu dengan cara dicuci menggunakan sabun kemudian dibilas dengan air hingga bersih, kemudian akuarium dan peralatan yang digunakan seperti selang aerasi dan batu aerasi direndam menggunakan kalium permanganat (PK) selama 24 jam, kemudian dibilas kembali dengan air mengalir. Akuarium kemudian diisi air setinggi $20 \mathrm{~cm}$ dan aerasi dipasang. Sebelum digunakan air dan sistem aerasi dibiarkan berjalan selama 24 jam untuk mensuplai kandungan oksigen dalam akuarium.

\section{Persiapan Tepung Eceng Gondok dan Kiambang}

Eceng gondok dan kiambang diperoleh dari perairan rawa yang ada di daerah Indralaya dan sekitarnya. Eceng gondok dan kiambang yang dipilih merupakan tanaman yang masih segar berwarna hijau dan yang diambil hanya bagian daun saja. Sebelum digunakan, eceng gondok dan kiambang dibersihkan terlebih dahulu dari kotoran yang menempel kemudian dipisahkan antara bagian daun dan dipotong-potong dengan ukuran $3 \mathrm{~cm}$ kemudian dikeringkan menggunakan oven selama 24 jam. Daun yang sudah kering kemudian dihaluskan menggunakan blender hingga halus, dan diayak sebelum digunakan.

\section{Pembuatan Pakan Perlakuan}

Pembuatan pakan perlakuan dilakukan dengan cara mencampur pelet komersil yang sudah dihaluskan dengan tepung eceng gondok dan kiambang sesuai perlakuan hingga homogen. Kemudian ditambahkan air hangat sebanyak $40 \%$ secara perlahan hingga adonan pakan kalis. Setelah itu, pakan dicetak menggunakan mesin pencetak pakan dan dikeringkan dibawah sinar matahari selama 2 hari. Setelah kering, pakan disimpan dalam wadah tertutup dan terhindar dari matahari langsung untuk menghindari pakan teroksidasi.

\section{Pemeliharaan Ikan}

Pemeliharaan ikan dilakukan di akuarium dengan padat tebar sebanyak 20 ekor per akuarium. Sebelum ditebar, ikan diadaptasikan terhadap pakan terlebih dahulu di akuarium stok selama 7 hari sampai ikan mau makan. Kemudian ikan dipuasakan selama 24 jam dan dihitung bobot dan panjangnya. Ikan diberikan pakan sesuai perlakan secara at satiation (sampai dengan ikan kenyang) sebanyak tiga kali sehari yaitu pukul 08.00, 12.00, dan 16.00 WIB. Pemeliharaan ikan dilakukan dilakukan selama 30 hari. 
Setiap 10 hari sekali dilakukan sampling untuk melihat pertumbuhan ikan. Setiap pagi hari dilakukan pengukuran kualitas air dan sifon untuk membuang sisa feses yang mengendap di dasar akuarium. Jika ada ikan yang mati, dilakukan penimbangan bobot dan diukur panjangnya.

\section{Parameter}

Jumlah konsumsi pakan

Jumlah konsumsi pakan (JKP)

ikan patin selama pemeliharaan dihitung menggunakan rumu sebagai berikut:

$\mathrm{JKP}=$ jumlah pakan awal - jumlah pakan akhir

\section{Pertumbuhan bobot mutlak}

Pertumbuhan bobot mutlak selama pemeliharaan dihitung dengan menggunakan rumus, sebagai berikut:

$$
\mathrm{W}=\mathrm{Wt}-\mathrm{W}_{0}
$$

Keterangan:

$$
\begin{aligned}
\mathrm{W}= & \text { Pertumbuhan bobot mutlak } \\
& \text { ikan }(\mathrm{g}) \\
\mathrm{Wt}= & \text { Bobot ikan pada akhir } \\
& \text { pemeliharaan }(\mathrm{g}) \\
\mathrm{W}_{0}= & \text { Bobot ikan pada awal } \\
& \text { pemeliharaan }(\mathrm{g})
\end{aligned}
$$

\section{Laju pertumbuhan spesifik (SGR)}

Laju pertumbuhan spesifik selama pemeliharaan dihitung dengan menggunakan rumus, sebagai berikut:

$$
S G R=\frac{(\operatorname{In} W t-\operatorname{In} W 0)}{t} \times 100 \% \mathrm{x}
$$

Keterangan:

SGR = Laju pertumbuhan spesifik (\%)

$\mathrm{Wt}=$ Bobot ikan akhir $(\mathrm{g})$
$\mathrm{W}_{0}=$ Bobot ikan uji awal $(\mathrm{g})$

$\mathrm{t}=$ Lama waktu pemeliharaan (hari)

\section{Efisiensi Pakan}

Efisiensi pakan selama pemeliharaan dihitung dengan menggunakan rumus, sebagai berikut:

$$
E P=\frac{[(\mathrm{Wt}+\mathrm{Wd})-\mathrm{Wo}]}{\mathrm{F}} \times 100 \%
$$

Keterangan:

$$
\begin{array}{rlr}
\mathrm{EP}= & \text { Efisiensi pakan }(\%) & \\
\mathrm{Wt}= & \text { Biomassa ikan akhir } \\
& \text { pemeliharaan }(\mathrm{g}) \\
\mathrm{Wd}= & \begin{array}{l}
\text { Biomassa ikan mati saat } \\
\text { pemeliharaan }(\mathrm{g})
\end{array} \\
\mathrm{W}_{0}= & \begin{array}{l}
\text { Biomassa ikan awal } \\
\text { pemeliharaan }(\mathrm{g})
\end{array} \\
\mathrm{F}= & \\
& \text { Jumlah total pakan yang } \\
& \text { dikonsumsi }(\mathrm{g})
\end{array}
$$

Survival Rate (SR)

Survival Rate atau

kelangsungan hidup selama

pemeliharaan dapat dihitung menggunakan rumus sebagai berikut:

$$
S R=\frac{N t}{N o} \times 100 \% \mathrm{x}
$$

Keterangan:

$$
\begin{aligned}
\mathrm{SR}= & \text { Kelangsungan hidup }(\%) \\
\mathrm{Nt}= & \text { Jumlah ikan pada akhir } \\
& \text { pemeliharaan }(\mathrm{g}) \\
\mathrm{N}_{0}= & \text { Jumlah ikan pada awal } \\
& \text { pemeliharaan }(\mathrm{g})
\end{aligned}
$$

\section{Analisis Data}

Data jumlah konsumsi pakan, pertumbuhan bobot mutlak, laju pertumbuhan spesifik, efisiensi pakan, dan kelangusungan hidup ikan yang diperoleh diolah menggunakan program microsoft excel, kemudian dianalisis ragam. Apabila terdapat 
perbedaan nyata maka dilanjutkan dengan uji lanjut BNT dengan taraf kepercayaan $95 \%$.

\section{Hasil dan Pembahasan}

Berdasarkan hasil penelitian diperoleh data jumlah konsumsi pakan, pertumbuhan bobot mutlak, laju pertumbuhan spesifik, efisiensi pakan, dan kelangsungan hidup ikan patin (Tabel 2). Hasil penelitian menunjukkan bahwa jumlah konsumsi pakan tidak berbeda nyata pada semua perlakuan.

Tabel 2. Jumlah konsumsi pakan (JKP), pertumbuhan bobot mutlak (W), laju pertumbuhan spesifik (SGR), efisiensi pakan (EP) dan kelangsungan hidup (SR) ikan patin selama pemeliharaan

\begin{tabular}{lccc}
\hline \multirow{2}{*}{ Parameter } & \multicolumn{3}{c}{ Perlakuan } \\
\cline { 2 - 4 } & P0 & P1 & P2 \\
\hline JKP $(\mathrm{g})$ & $119,99 \pm 5,06^{\mathrm{a}}$ & $119,71 \pm 0,50^{\mathrm{a}}$ & $117,95 \pm 3,34^{\mathrm{a}}$ \\
$\mathrm{W}(\mathrm{g})$ & $2,46 \pm 0,37^{\mathrm{a}}$ & $2,78 \pm 0,09^{\mathrm{a}}$ & $3,84 \pm 0,83^{\mathrm{b}}$ \\
SGR \% & $1,49 \pm 0,19^{\mathrm{a}}$ & $1,65 \pm 0,12^{\mathrm{a}}$ & $2,07 \pm 0,28^{\mathrm{b}}$ \\
EP $(\%)$ & $41,17 \pm 6,13^{\mathrm{a}}$ & $42,88 \pm 4,86^{\mathrm{a}}$ & $59,96 \pm 9,14^{\mathrm{b}}$ \\
SR $(\%)$ & $100 \pm 0,00^{\mathrm{a}}$ & $96,67 \pm 5,77^{\mathrm{a}}$ & $90,00 \pm 8,66^{\mathrm{a}}$ \\
\hline
\end{tabular}

Keterangan: Huruf superskrip yang berbeda pada baris yang sama menunjukkan nilai yangberbeda nyata $(\mathrm{P}<0,05)$

Jumlah konsumsi pakan dipengaruhi oleh palatabilitas ikan terhadap pakan. Faktor yang mempengaruhi palatabilitas diantaranya bau atau aroma, tekstur dan rasa (Putranti et al., 2017). Diduga semua pakan memiliki palatabilitas yang sama sehingga tidak mempengaruhi jumlah konsumsi pakan.

Pertumbuhan bobot mutlak ikan yang dihasilkan pada penelitian ini menunjukkan hasil yang berbeda nyata. Nilai pertumbuhan bobot mutlak ikan patin tertinggi terdapat pada perlakuan P2 sebesar 3,84 g sedangkan pada perlakuan P0 dan P1 menunjukkan hasil yang tidak berbeda nyata yaitu masing-masing sebesar 2,46 g dan 2,78 g. Laju pertumbuhan spesifik tertinggi terdapat pada perlakuan P2 (penambahan kiambang) sebesar $2,07 \%$ sedangkan pada perlakuan P0 dan P1 masing masing sebesar $1,49 \%$ dan $1,65 \%$ menunjukkan hasil yang tidak berbeda nyata. Ikan mengalami pertumbuhan apabila pakan yang dikonsumsi mampu memenuhi kebutuhan nutrisinya.

Pertumbuhan ikan terjadi karena adanya kelebihan energi hasil pencernaan makanan yang digunakan untuk maintenance. Pertumbuhan ikan pada perlakuan P2 lebih tinggi dikarenakan ikan patin lebih mampu memanfaatkan pakan yang mengandung kiambang dibandingkan yang mengandung eceng gondok. Hal ini dikarenakan perbedaan nutrisi yang terkandung dalam kiambang dan eceng gondok. Kiambang mengandung protein yang lebih tinggi dan serat kasar yang lebih rendah dibandingkan eceng gondok sehingga pertumbuhan ikan pada perlakuan P2 lebih tinggi dibandingkan P1. Protein berperan terhadap pertumbuhan yang digunakan sebagai energi utama yang dimanfaatkan ikan. Menurut Khalil et 
al. (2015) melaporkan bahwa ikan nila yang diberikan pakan berupa tanaman air yang berbeda menghasilkan pertumbuhan yang juga berbeda. Permana et al. (2015) menyatakan bahwa kandungan serat kasar yang tinggi akan mempengaruhi daya cerna ikan dan penyerapan energi dalam pakan sehingga menghasilkan pertumbuhan yang rendah. Pada perlakuan P0 menghasilkan pertumbuhan yang rendah diduga karena kandungan nutrisi pakan komersil yang digunakan belum mencukupi untuk kebutuhan nutrisi ikan patin.

Efisiensi pakan merupakan perbandingan pertumbuhan bobot ikan dengan jumlah pakan yang dikonsumsi. Nilai efisiensi pakan yang tinggi menunjukkan bahwa semakin efisien ikan dalam memanfaatkan pakan yang dikonsumsi untuk pertumbuhan (Amin et al., 2020). Berdasarkan analisis ragam, nilai efisiensi pakan menunjukkan hasil yang berbeda nyata. Efisiensi pakan tertinggi terdapat pada perlakuan P2 yaitu sebesar $59,96 \%$ sedangkan pada perlakuan P1 dan P2 masing-masing sebesar $41,17 \%$, dan $42,88 \%$ menunjukkan hasil yang tidak berbeda nyata. Nilai efisiensi pakan perlakuan dengan penambahan kiambang menghasilkan nilai efisiensi yang tinggi karena lebih dari 50\%. Craig dan Helfrich (2002) dalam Faziel et al. (2017) menyatakan bahwa pakan dapat dikatakan baik bila nilai efisiensi pemberian pakan lebih dari $50 \%$ atau bahkan mendekati $100 \%$. Nilai efisiensi pakan yang tinggi pada perlakuan P2 menunjukkan bahwa pakan tersebut memiliki kualitas yang baik. Salah satu parameter suatu pakan dikatakan baik apabila mengandung nutrisi yang diperlukan oleh tubuh baik jumlah maupun jenisnya. Salah satu nutrisi tersebut adalah kandungan asam amino. Kiambang mengandung asam amino esensial yang lebih lengkap dibandingkan eceng gondok. Menurut Leterme et al. (2009) dalam Ridhwan (2019) kiambang memiliki asam amino esensial dan non esensial diantaranya metionin, valin, trytofan, theonin, leusin, dan lysine,isoleusin, histidin, arginin dan penilalanin sedangkan eceng gondok mengandung asam amino metionin, valin, trytofan, tyrosin, leusin, dan lysine (Nyananyo et al., 2007 dalam Wijaya et al., 2015)

Berdasarkan hasil analisis ragam bahwa kelangsungan hidup pada penelitian ini menghasilkan hasil yang tidak berbeda nyata. Kelangsungan hidup dipengaruhi oleh pakan dan kondisi lingkungan. Hal ini membuktikan bahwa penambahan eceng gondok dan kiambang tidak mempengaruhi kualitas lingkungan ikan patin. Suhu pada media pemeliharaan berkisar $25,8-27,5^{\circ} \mathrm{C}$ sedangkan $\mathrm{pH}$ berkisar 6,16 - 7,0 masih dalam kisaran toleransi pemeliharaan ikan patin. Berdasarkan Septimesy et al. (2016) menyatakan bahwa suhu $26-28{ }^{\circ} \mathrm{C}$ dan pH 6- 7 masih masuk kisaran kualitas air yang normal untuk ikan patin.

\section{Kesimpulan}

Penambahan eceng gondok (P1) pada pakan tidak memberikan pengaruh sedangkan penambahan kiambang (P2) memberikan pengaruh 
nyata terhadap pertumbuhan bobot mutlak, laju pertumbuhan spesifik, dan efisiensi pakan ikan patin (Pangasius sp.). Penambahan eceng gondok dan kiambang masingmasing sebesar $25 \%$ pada pakan mampu mengurangi penggunaan pakan komersil. Penambahan kiambang pada pakan (P2) merupakan perlakuan yang terbaik yang menghasilkan nilai pertumbuhan bobot mutlak $3,84 \mathrm{~g}$, laju pertumbuhan spesifik 2,07\%, dan efisiensi pakan 59,96\%.

\section{Daftar Pustaka}

Amin, M., Taqwa, F.T, Yulisman, Mukti, R.C., Rarassari, M.A., dan Antika, R.M. 2020. Efektivitas Pemanfaatan Bahan Baku Lokal Sebagai Pakan Ikan Terhadap Peningkatan Produktivitas Budidaya Ikan Lele (Clarias sp.) di Desa Sakatiga, Kecamatan Indralaya, Kabupaten Ogan Ilir, Sumatera Selatan. Journal of Aquaculture and Fish Health, 9(3): 222-231

Astuti, L.P, dan Indriatmoko. 2018. Kemampuan Beberapa Tumbuhan Air dalam Menurunkan Pencemaran Bahan Organik dan Fosfat untuk Memperbaiki Kualitas Air. Jurnal Teknologi Lingkungan, 19(2): 183-190

Faziel, M., Yulvizar, C., dan Hasri, I. 2017. Pengaruh Suplemen Dan Probiotik Pada Pakan Terhadap Pertumbuhan Dan Kelangsungan Hidup Larva Ikan Peres (Osteochilus viittatus). Jurnal Ilmiah Mahasiswa Kelautan Dan Perikanan, 2(1): 158-168
Iskandar, R., dan Elrifadah. 2015. Pertumbuhan dan Efisiensi Pakan Ikan Nila (Oreochromis niloticus) yang Diberi Pakan Buatan Berbasis Kiambang. Jurnal Ziraa"ah, 40(1): 18-24

Khalil, M., Maulana, R., dan Rusydi, R. 2015. Efektifitas Beberapa Jenis Tanaman Air sebagai Pakan Alam Terhadap Pertumbuhan Benih Ikan Nila Gesit (Oreochromis niloticus). Samudera, Jurnal Penelitian Ilmu-Ilmu Alam Dan Teknik, 9(2): 89-102

Mukti, R.C, Yonarta, D., dan Pangawikan, A.D. 2019. Pemanfaatan Daun Indigofera zollingeriana Sebagai Bahan Pakan Ikan Patin Pangasius sp. DEPIK Jurnal Ilmu-Ilmu Perairan, Pesisir dan Perikanan, 8(1): 18-25

NRC (National Research Council). 1993. Subcommite on Warmwater Fish Nutrition.. Nutrient requirements of fish. Washington DC : National Academy of science, $114 \mathrm{pp}$. Peres H. dan Teles A.O.

Permana, N.A., Cahyoko, Y., dan Arief, M. 2015. Substitusi Tepung Ikan Dengan Tepung Limbah Ikan Hiu (Carcharhinus sp.) Terhadap Pertumbuhan, Efisiensi Pakan Dan Survival Rate Ikan Lele Dumbo. Jurnal Ilmiah Perikanan Dan Kelautan, 7(2): 199-206

Putranti, G.P., Subandiyono, dan Pinandoyo. 2017. Pengaruh Protein dan Energi yang berbeda pada Pakan Buatan Terhadap Efisiensi Pemanfaatan Pakan dan 
Pertumbuhan Ikan Mas (Cyprinus carpio). Journal of Aquaculture Management and Technology, 4(3): 95-100.

Ramadhana, S. 2020. Penambahan Ekstrak Kiambang (Salvina molest D.S. Mitchell) pada Pellet Industri Dengan Persentase Yang Berbeda Terhadap Pertumbuhan Ikan Betok (Anabas testudineus). Prosiding Seminar Nasional Lingkungan Lahan Basah, 5(3): 32-34

Razikin, M., Sumahirdewi, L.G., dan Liliyanti, M.A. 2019. Pemanfaatan Eceng Gondok sebagai Bahan Baku Pakan Buatan untuk Benih Ikan Nila (Oreochomis niloticus). Indonesian Journal of Aquaculture and Fisheries (IJAF), 1(1): 55-66

Ridhwan, M. 2019. Kandungan Fraksi Serat Silase Tanaman Kiambang (Salvinia molesta) Yang Difermentasi Dengan Effective Microorganisme (EM4) Dengan Level Yang Berbeda. Skripsi. Universitas Islam Negeri Sultan Syarif Kasim, Riau.

Septimesy, A., Jubaedah, D., dan Sasanti, $\quad$ A.D. 2016. Pertumbuhan dan Kelangsungan Hidup Ikan Patin (Pangasius sp) di Sistem Resirkulasi dengan Padat Tebar Berbeda. Jurnal Akuakultur Rawa Indonesia, 4(1): 1-8

Suprayudi, M.A., 2010. Bahan Baku Lokal: Tantangan dan Harapan Akuakultur Masa Depan. Prosiding Simposium Nasional Bioteknologi Akuakultur III. IPB
International Convention Center, Bogor, Oktober 2010. Hal 31

Sulhi, M. 2015. Substitusi Tepung Kedelai dengan Tepung Eceng Gondok Hasil Fermentasi dalam Formulasi Pakan terhadap Pertumbuhan dan Sintasan Benih Gurame (Osphronemus gouramy Lac.). Prosiding Forum Inovasi Teknologi Akuakultur, 319-326 Warasto, Yulisman, dan Firani, M. 2013. Tepung Kiambang (Salvina molesta) Terfermentasi Sebagai Bahan Pakan Ikan Nila (Oreochromis niloticus). Jurnal Akuakultur Rawa Indonesia, 1(2): 173-183

Wijaya, D., Yanti, P.P., Setya A.R., dan Rizal, M. 2015. Screening Fitokimia dan Aktivitas Antioksidan Daun Eceng Gondok (Eichhornia crassipes). Jurnal Kimia VALENSI: Jurnal Penelitian dan Pengembangan Ilmu Kimia, 1(1): 65-69

Yuniati, D., Utomo, N.B.P., Setiawati, M., dan Alimuddin. 2018. Growth performance and enzyme activities in catfish (Pangasianodon hypophthalmus) fed with water hyacinth-based diet. Biotropia, 25(2): 140-147 